\title{
Developing Students' Prosocial Behavior based on their Value Orientations
}

\author{
Muhammad Asrori \\ Study Program of Guidance and Counseling, Department of Educational Science, \\ Faculty of Teachers Training and Education, University of Tanjungpura \\ Pontianak, Indonesia \\ asroriuntan@yahoo.com
}

\begin{abstract}
The purpose of this study was to develop new guidance model, namely "Prosocial Guidance Model". Developing students' prosocial behavior is a very important program in the living situation that increasingly complicated, individualistic, and hedonistic. In this study, 250 Junior High School students over West Kalimantan were involved as a participant. Inventory of prosocial and inventory of value orientation was used as a research instrument. The distribution of frequency and analysis of variance was used to data analysis. The findings indicate that: (1) The Junior High School students' prosocial behavior was on the "lower level" over all its aspects accept "collaboration" aspect. There was no difference viewed from school differences. (2) The Junior High School students' value orientations were on the "moderate" level. The dominant value was "religious value" and "solidarity value" that they were on the "high level." (3) Based on the Effect Size, the "solidarity value" and "art value" were having a significant effect on the students' prosocial behavior $(E S=.69$ and .50$)$.
\end{abstract}

Keywords-prosocial, altruism, value orientation, individual factors, situational factors, guidance model

\section{INTRODUCTION}

The current living situation is increasingly complicated. The acceleration of the technology of informationcommunication has massively brought new values. As a result, established values are challenged and become shaky. According to [1], such a life complexity is predicted to become more and more complicated in the future so that the human beings, including the Junior High School students who are looking for their ego-identity are increasingly led to a very competitive pattern of life. Furthermore, they tend to lead to the individualistic and materialistic pattern of life.

The future complexity challenge leads to the two alternatives: to accept their faith or to get well-prepared. Certainly, the educational missions included the counseling missions, which have future dimensions leads to the second alternative.

One of the educational efforts is the development of their prosocial behavior. It is important because the prosocial behavior is voluntary behavior intended to benefit another, a social behavior that benefits other people or society as a whole such as helping, sharing, donating, cooperating, and volunteering [2]. The purest forms of prosocial behavior are motivated by altruism, an unselfish interest in helping another person. According to [3], these actions may be motivated by empathy and by concern about the welfare and right other as well as for egoistic or practical concern. Furthermore, [3] said that the circumstances most likely to evoke altruism are empathy for an individual in need or a close relationship between the benefactor and the recipient

Prosocial is defined as actions that benefit other people or society as a whole [4]. In this context [5] emphasizing that prosocial behavior refers to voluntary actions are intended to help or benefit another individual or group of individuals. This definition refers to consequences of a doer's action rather than the motivations behind those actions. It is characterized by helping that does not benefit the helper. In fact, prosocial behavior includes a broad range of activities: sharing, comforting, rescuing, and helping.

Evidence suggests that prosociality is central to the wellbeing of social groups across a range of scale [6][7]. Empathy is a strong motive in eliciting prosocial behavior and has deep evolutionary roots [8]. Prosocial behavior fosters positive traits that are beneficial for children and society. It may be motivated both by altruism and by self-interest, for reasons of immediate benefit or future reciprocity.

Encouraging prosocial behavior may also require decreasing or eliminating undesirable social behavior [7]. However, many prosocial behaviors that appear altruistic are in fact motivated by the norm of reciprocity, which is the obligation to return a favor with a favor. People feel guilty when they do not reciprocate and they may feel angry when someone else does not reciprocate. According to [9] that altruism may not exist and is completely motivated by reciprocity. In this context, [10] [11] explained that reciprocity or altruism may motivate many important prosocial behaviors such as philanthropist and rescuer.

Prosocial behavior motivated or affected by both individual and situational determinant factors. According to [12] the individual determinant factors that affect the prosocial behavior are age, sex, cognitive development, personality traits, and value orientations. On the other side, the situational determinant factors are socialization through parental caring, parent as a model, effective relationship between child and parent, teaching method of teacher and parent, and structure and family function.

Value orientations the principles of right or wrong that are accepted by an individual or a social group [13]. The value 
orientation reveals an individual's worldviews, their assumptions about life and perceptual orientations. In this context, [14] said that value system represents core intelligence and act as a decision-making framework that guides behavior and life choices. Value system thus provides a structure for thinking, act as organizing principles, and guides an individual's mode of adaptation to the world. Furthermore, [15] emphasize that value are like fingerprints. No body's the same, but we leave them all over everything we do.

Values related to the norms of culture but they are more global and abstract than norms. Norms provide rules for behavior in specific situations, while values identify what should be judged as good or evil. Values tend to elicit strong, unconscious emotions.

The individual value standard, social standard and ideal self of individuals are able to motivate many importance prosocial behaviors. In this context, [16] emphasize that social responsibility norms and reciprocity norms are also important factors that strengthen to the prosocial behavior. Value standard that has been a self-norm or moral norm of person is able to strongly motivate much importance prosocial behavior. A research of [17] has proved that moral norm is an important predictor variable for the person to be a philanthropist, rescuer, and other many importance prosocial behavior. Furthermore, [17] described that several studies have indicated a positive relationship between prosocial behavior and religion.

Refer to [12] this research conducted to analyze deeply about the effect of value orientation as an individual factor to students' prosocial behavior. Furthermore, establishing prosocial guidance model.

The value orientation that involved in this research based on the Spranger's theory of value. According to [13] was defined as an order whether religion order, social order, cultural order, or moral order that be the base of individual judgment on his or her behavior decision.

Based on the background of research, there are research questions: (1) how is the profile of students' prosocial behaviors? (2) What is students' dominant value orientation? (3) To what extent is the students' value orientation affect to their prosocial behavior?

The expected result of the research is establishing the prosocial guidance model. Theoretically, this research contributes to developing "science of prevention and development" especially in the counseling discipline. So, the counseling discipline is not only reclusive in the students' problem solving but to be rich of developing students' potential. On the other hand, practically this research contributes the prosocial guidance model as a new alternative to positive behavior modification technique.

\section{METHOD}

\section{A. Research Variables}

There two research variables were involved in this research: (1) value orientation that based on the Spranger's theory [13] which has six sub-variables: theory/scientific value, economic value, social/solidarity value, religious value, art value, and power value. (2) Prosocial behavior that based on Galen's theory [17] which have five sub-variables: sharing, cooperation, concern for others' rights and welfare, and caring for others.

\section{B. Subject and Location of Research}

The research subject is eight grade State Junior High School students in Pontianak and Singkawang district, they are SMP Negeri 3 Pontianak, SMP Negeri 2 Pontianak, SMP Negeri 7 Pontianak, SMP Negeri 1 Singkawang, SMP Negeri 5 Singkawang, and SMP Negeri Sedau. The area proportional random sampling was used [18], so there are 250 students as a participant. The instrument was used in this study are Inventory of Value Orientations and Inventory of Prosocial Behavior summated rating with five answer alternatives. The reliability coefficient of interrater of value orientation inventory is 0.74 and instrument reliability is 0.86 . The reliability coefficient of interrater of prosocial behavior inventory is 0.83 and instrument reliability is 0.81 .

Data analysis techniques used in this study are the distribution of frequency [19] and analysis of variance and effect size analysis [20]. Normality test was done using Liliefors test and homogeneity test using Barlett's test [21].

\section{RESEARCH RESULT AND DISCUSSION}

\section{A. Research Result}

1) Profile of Students' Prosocial Behavior

Based on the normal curve can be made a category of students' prosocial behavior Table 1 .

TABLE I. CATEGORY OF STUDENTS’ PROSOCIAL BEHAVIOR

\begin{tabular}{|c|c|c|c|}
\hline No. & Range of Score & Percentage & Category \\
\hline 1. & $00.00-39.00$ & $00.00 \%-32.50 \%$ & Lower \\
\hline 2. & $40.00-80.00$ & $33.33 \%-66.67 \%$ & Moderate \\
\hline 3. & $81.00-120.00$ & $67.50-100.00 \%$ & High \\
\hline
\end{tabular}

Refer to the category on Table 1 the profile of students' prosocial behavior as overall and its aspects can be described such as in Table II.

\section{TABLE II. PROFILE OF STUDENTS’ PROSOCIAL BEHAVIOR}

\begin{tabular}{|l|c|c|c|}
\hline \multicolumn{1}{|c|}{$\begin{array}{c}\text { Variable/ } \\
\text { Sub Variable }\end{array}$} & $\begin{array}{c}\text { Ideal } \\
\text { Score }\end{array}$ & Actual Score & $\begin{array}{c}\text { Percentage } \\
\text { (Category) }\end{array}$ \\
\hline $\begin{array}{l}\text { Students' prosocial } \\
\text { behavior }\end{array}$ & 28920 & 9254 & $31.99 \%(\mathrm{~L})$ \\
\hline A. Sharing & 7230 & 2169 & $30.00 \%(\mathrm{~L})$ \\
\hline B. Cooperation & 7230 & 2750 & $38.04 \%(\mathrm{M})$ \\
\hline $\begin{array}{l}\text { C. Concern for the } \\
\text { others' rights and } \\
\text { welfare }\end{array}$ & 7230 & 2277 & $31.49 \%(\mathrm{M})$ \\
\hline C. Caring for others & 7230 & 2313 & $31.99 \%(\mathrm{M})$ \\
\hline
\end{tabular}

Table II shows that students' prosocial behaviors tend to the "lower level". If analyzed its aspect shows that only the "cooperation" aspect that tends to the "moderate level." It indicated that students' prosocial behavior must be developed systematically by design because prosocial behavior very importance to face the living situation that increasingly complicated and tend to individualistic, materialistic, and 
hedonistic. One of the efforts is conducting systematically guidance and counseling program by "Prosocial Guidance Model."

2) Difference of Students' Prosocial Behavior Interschool

Variance homogeneity testing was carried out before data analysis by analysis of variance such as illustrated in Table 3 .

Table III shows that result of variance homogeneity testing of students' prosocial behavior whether overall or each aspect is not significant on $\mathrm{p}<0.05$. It is mean that statistic assumption to analyze the difference of students' prosocial behavior interschool by analysis of variance can be carried out.

TABLE III. VARIANCE HOMOGENEITY TESTING OF STUDENTS' PROSOCIAL BEHAVIOR

\begin{tabular}{|c|c|c|c|c|}
\hline Aspect & Levine Statistic & df1 & df2 & Sig. \\
\hline 1 & 0.812 & 6 & 234 & 0.562 \\
\hline 2 & 1.074 & 6 & 234 & 0.379 \\
\hline 3 & 1.835 & 6 & 234 & 0.093 \\
\hline 4 & 1.255 & 6 & 234 & 0.279 \\
\hline Overall & 1.205 & 6 & 234 & 0.305 \\
\hline
\end{tabular}

To analyze the difference of students' prosocial behavior interschool carried out by analysis of variance. Its result can be viewed in Table IV.

TABLE IV. DIFFERENCE OF STUDENTS' PROSOCIAL BEHAVIOR INTERSCHOOL

\begin{tabular}{|l|c|c|c|c|c|}
\hline & $\begin{array}{c}\text { Sum of } \\
\text { Squares }\end{array}$ & Df & $\begin{array}{c}\text { Mean } \\
\text { Square }\end{array}$ & F & Sig. \\
\hline $\begin{array}{l}\text { Between } \\
\text { Groups }\end{array}$ & 427.00 & 6 & 71.17 & 1.29 & 0,26 \\
\hline $\begin{array}{l}\text { Within } \\
\text { Groups }\end{array}$ & 12936.66 & 234 & 55.29 & & \\
\hline Total & 13363.67 & 240 & & & \\
\hline
\end{tabular}

Table IV shows that viewed from interschool is there is no difference students' prosocial behavior between one school and another. It is mean that students' prosocial behavior tends to the lower level all of the schools.

In order to understand specifically each aspect of students' prosocial behavior the analysis of variance of each aspect was also carried out. The result such as illustrated in Table V.

TABLE V. DIFFERENCE OF STUDENTS' PROSOCIAL BEHAVIOR ASPECTS INTERSCHOOL

\begin{tabular}{|c|l|c|c|c|c|c|}
\hline Aspect & & $\begin{array}{c}\text { Sum of } \\
\text { Squares }\end{array}$ & df & Mean Square & F & Sig. \\
\hline 1 & Between & 49.71 & 6 & 8.29 & 1.79 & 0.10 \\
& Within & 1083.46 & 234 & 4.63 & & \\
\hline & Total & 1133,17 & 240 & & & \\
\hline 2 & Between & 25.37 & 6 & 4.23 & 0.59 & 0.74 \\
& Within & 1671.73 & 234 & 7.14 & & \\
& Total & 1697.10 & 240 & & & \\
\hline 3 & Between & 71.08 & 6 & 11.85 & 2.39 & 0.03 \\
& Within & 1162.32 & 234 & 4.97 & & \\
\hline \multirow{2}{*}{4} & Total & 1233.40 & 240 & & & \\
& Between & 51.34 & 6 & 8.56 & 1.73 & 0.12 \\
& Within & 1160.27 & 234 & 4.99 & & \\
& Total & 1211.61 & 240 & & & \\
\hline
\end{tabular}

Table V shows that also no significant differences aspects of students' prosocial behavior between one school and another. From overall aspects of prosocial behavior is only the aspect of "caring for others' rights and welfare" that have a significant difference. All of the others are no significant differences.

\section{3) Profile of Students' Value Orientations}

Based on the normal curve can be made the category of students' value orientations such as Table VI.

\section{TABLE VI. CATEGORY OF STUDENTS' VALUE ORIENTATIONS}

\begin{tabular}{|c|c|c|c|}
\hline No & Range of Score & Percentage & Category \\
\hline 1. & $00.00-39.00$ & $00.00 \%-32.50 \%$ & Lower \\
\hline 2. & $40.00-80.00$ & $33.33 \%-66.67 \%$ & Moderate \\
\hline 3. & $81.00-120.00$ & $67.50-100.00 \%$ & High \\
\hline
\end{tabular}

Refer to the category on Table 6 the profile of students' value orientations as overall and its aspect can be described in Table VII.

TABLE VII. PROFILE OF STUDENTS' VALUE ORIENTATIONS

\begin{tabular}{|l|c|c|c|}
\hline $\begin{array}{c}\text { Variable/ } \\
\text { Sub Variable }\end{array}$ & Ideal Score & $\begin{array}{c}\text { Actual } \\
\text { Score }\end{array}$ & $\begin{array}{c}\text { Percentage } \\
\text { (Category) }\end{array}$ \\
\hline $\begin{array}{l}\text { Students' value } \\
\text { orientations }\end{array}$ & 29940 & 11497 & $38.40 \%(\mathrm{M})$ \\
\hline A. $\quad$ Scientific value & 7580 & 2350 & $31.00 \%(\mathrm{~L})$ \\
\hline B. $\quad$ Economic value & 7580 & 2358 & $38.04 \%(\mathrm{M})$ \\
\hline C. $\quad$ Solidarity value & 7580 & 5267 & $69.49 \%(\mathrm{H})$ \\
\hline D. $\quad$ Religious value & 7580 & 5376 & $70.93 \%(\mathrm{H})$ \\
\hline E. $\quad$ Art value & 7580 & 2282 & $30.10 \%(\mathrm{~L})$ \\
\hline F. $\quad$ Power value & 7580 & 2830 & $37.34 \%(\mathrm{M})$ \\
\hline
\end{tabular}

Table VII shows that overall of students' value orientations tend to "moderate" level. If analyzed specifically to its aspects show that aspects of "solidarity value and religious value" have tended to the "high level" whereas aspects of "scientific value and art value" tend to the "lower level." On the other side, the aspects of "economic value" and "power value" tend to the "moderate level."

\section{4) Difference of Students' Value Orientations}

Variance homogeneity testing was carried out before data analysis by analysis of variance such as illustrated in Table VIII.

Table VIII shows that result of variance homogeneity testing of students' value orientations whether overall or each aspect is not significant on $p<0.05$. It is mean that statistic assumption to analyze the difference of students' value orientations interschool by analysis of variance can be carried out. 
TABLE VIII. VARIANCE HOMOGENEITY TESTING OF STUDENTS' VALUE ORIENTATIONS

\begin{tabular}{|c|c|c|c|c|}
\hline Aspect & Levine Statistic & df1 & df2 & Sig. \\
\hline 1 & 0,815 & 6 & 234 & 0,566 \\
\hline 2 & 1,077 & 6 & 234 & 0,386 \\
\hline 3 & 1,838 & 6 & 234 & 0,099 \\
\hline 4 & 1,759 & 6 & 234 & 0,284 \\
\hline 5 & 1,260 & 6 & 234 & 0,310 \\
\hline 6 & 1,379 & 6 & 234 & 0,353 \\
\hline Overall & 1,221 & 6 & 234 & 0,335 \\
\hline
\end{tabular}

To analyze the difference of students' value orientations interschool carried out by analysis of variance. Its result can be viewed in Table IX.

\section{TABLE IX. DIFFERENCE OF STUDENTS' VALUE ORIENTATIONS} INTERSCHOOL

\begin{tabular}{|l|c|c|c|c|c|}
\hline & $\begin{array}{c}\text { Sum of } \\
\text { Squares }\end{array}$ & Df & $\begin{array}{c}\text { Mean } \\
\text { Square }\end{array}$ & F & Sig. \\
\hline $\begin{array}{l}\text { Between } \\
\text { Groups }\end{array}$ & 430.01 & 6 & 73.17 & 1.29 & 0.27 \\
\hline $\begin{array}{l}\text { Within } \\
\text { Groups }\end{array}$ & 12939.67 & 234 & 57.29 & & \\
\hline Total & 13369.68 & 240 & & & \\
\hline
\end{tabular}

Table IX shows that viewed from interschool there are no difference students' value orientations between one school and another. It is mean that students' value orientations tend to the "moderate level" all of the schools.

In order to understand specifically each aspect of students' value orientations, the analysis of variance of each aspect was also carried out. The result such as illustrated in Table X.

TABLE X. DIFFERENCE OF STUDENTS' VALUE ORIENTATIONS ASPECTS INTERSCHOOL

\begin{tabular}{|c|c|c|c|c|c|c|}
\hline Aspect & & $\begin{array}{c}\text { Sum of } \\
\text { Squares }\end{array}$ & Df & $\begin{array}{c}\text { Mean } \\
\text { Square }\end{array}$ & $\mathbf{F}$ & Sig. \\
\hline 1 & $\begin{array}{l}\text { Between } \\
\text { Within } \\
\text { Total } \\
\end{array}$ & $\begin{array}{c}23.37 \\
1641.62 \\
1664.99 \\
\end{array}$ & $\begin{array}{c}6 \\
234 \\
240 \\
\end{array}$ & $\begin{array}{l}3.48 \\
6.24\end{array}$ & 0.56 & 0.65 \\
\hline 2 & $\begin{array}{l}\text { Between } \\
\text { Within } \\
\text { Total } \\
\end{array}$ & $\begin{array}{c}49.72 \\
1083.47 \\
1133.19 \\
\end{array}$ & $\begin{array}{c}6 \\
234 \\
240 \\
\end{array}$ & $\begin{array}{l}8.29 \\
4.63\end{array}$ & 1.79 & 0.10 \\
\hline 3 & $\begin{array}{l}\text { Between } \\
\text { Within } \\
\text { Total } \\
\end{array}$ & $\begin{array}{c}71.09 \\
1162.34 \\
1233.43 \\
\end{array}$ & $\begin{array}{c}6 \\
234 \\
240 \\
\end{array}$ & $\begin{array}{c}11.85 \\
4.97\end{array}$ & 2.39 & 0.03 \\
\hline 4 & $\begin{array}{l}\text { Between } \\
\text { Within } \\
\text { Total } \\
\end{array}$ & $\begin{array}{c}71.36 \\
1160.27 \\
1231.27 \\
\end{array}$ & $\begin{array}{c}6 \\
234 \\
240 \\
\end{array}$ & $\begin{array}{l}8.56 \\
4.96\end{array}$ & 1.73 & 0.12 \\
\hline 5 & \begin{tabular}{|l|} 
Between \\
Within \\
Total \\
\end{tabular} & $\begin{array}{c}25.37 \\
1671.75 \\
1697.13 \\
\end{array}$ & $\begin{array}{c}6 \\
234 \\
240 \\
\end{array}$ & $\begin{array}{l}4.23 \\
7.14\end{array}$ & 0.59 & 0.74 \\
\hline 6 & $\begin{array}{l}\text { Between } \\
\text { Within } \\
\text { Total } \\
\end{array}$ & $\begin{array}{c}48,894 \\
1134.63 \\
1183.52 \\
\end{array}$ & $\begin{array}{c}6 \\
234 \\
240 \\
\end{array}$ & $\begin{array}{l}7.48 \\
4.90\end{array}$ & 1.67 & 0.10 \\
\hline
\end{tabular}

Table $\mathrm{X}$ shows that also no significant differences aspects of students' value orientations between one school and another. From overall aspects of value, orientation is only the aspects of "solidarity value and religious value" that have a significant difference. Whereas the other four aspects, they are "scientific value, economic value, art value, and power value" there are no significant differences.
5) Difference of Students' Prosocial Behavior Based on Their Value Orientations

The difference of students' prosocial behavior based on their value orientations is analyzed by effect size technique. The magnitude of effect size indicates the effect of students' value orientation to their prosocial behavior. In this study, the significance of coefficient effect size is 0.50 . The result of effect size analysis students' value orientations to their prosocial behavior is illustrated in Table XI.

\section{TABLE XI. EFFECT SIZE STUDENTS' VALUE ORIENTATIONS TO} THEIR PROSOCIAL BEHAVIOR

\begin{tabular}{|c|l|c|c|c|}
\hline No. & \multicolumn{1}{|c|}{$\begin{array}{c}\text { Students' Value } \\
\text { Orientations }\end{array}$} & $\begin{array}{c}\text { Sum of } \\
\text { Squares }\end{array}$ & $\begin{array}{c}\text { Mean } \\
\text { Square }\end{array}$ & $\begin{array}{c}\text { Effect } \\
\text { Size }\end{array}$ \\
\hline 1. & Scientific value & 1664.99 & 3.483 & 0.37 \\
\hline 2. & Economic value & 1133.19 & 8.285 & 0.46 \\
\hline 3. & Solidarity value & 1233.43 & 11.847 & 0.69 \\
\hline 4. & Religious value & 1231.27 & 8.56 & 0.47 \\
\hline 5. & Art value & 1697.13 & 4.23 & 0.50 \\
\hline 6. & Power value & 1183.52 & 7.48 & 0.39 \\
\hline
\end{tabular}

Table XI shows that have no significant effect on students' prosocial behavior are "scientific value" $(E S=0.37)$ and "power value" ( $E S=0.39)$. The "economic value" $(E S=0.46)$ and "religious value" ( $E S=0.47)$ are also lack of significance to the students' prosocial behavior. On the other side, that has a significant effect on the prosocial behavior is "solidarity value" $(E S=0.69)$ and "art value" $(E S=0.50)$.

\section{B. Discussion}

It is understood that scientific value and economic value have no significant effect on students' prosocial behavior. The argument is the scientific value tend lead individual to act based on the logical thinking. Furthermore, the economic value tends lead person to act based on the judgment of rate of return. On the other hand, prosocial behavior is voluntary behavior intended to benefit another, a social behavior that benefits other people or society as a whole such as helping, sharing, donating, cooperating, and volunteering [2]. The purest forms of prosocial behavior are motivated by altruism, an unselfish interest in helping another person. Frequently, according to [22], prosocial behavior is not required analytical or logical thinking.

Such was the case, the power value also has no significant effect on students' prosocial behavior. It is reasonable because according to [23] the power value tends to lead an individual to dominate others that cause he or she is not interested in helping or caring others without able to dominate them.

It is very interesting that a finding of this study indicates that religious value is lack of significant effect of students' prosocial behavior. Isn't that every religion teach all person to love others? Isn't that every religion also teach all person to help others? There is a bright argument from [24] that in reciting religious value in context to prosocial behavior must distinguish to "religious affection" and "religious behavior". He emphasizing that religious affection is not always manifest to the religious behavior. The consequence of this point of 
view is that individual, including students, with well religious affection, is not automatically manifest to prosocial behavior.

There is a consistency finding that solidarity value is has a significant effect on students' prosocial behavior. It is understood because according to [25] explained that one of the essences of prosocial behavior is solidarity. [16] also argue that solidarity that developed in the individual self-tend to lead him or her to increase respect for dignity and valence of others.

Finally, there is interesting finding that art value has a significant effect on students' prosocial behavior. It is consistency to [26] which argue that art value is able to lead an individual to develop sensitivity of feeling, the sensitivity of crisis, and empathy. All of them if developed in the personality of person are able to race their prosocial behavior.

\section{CONCLUSION AND RECOMMENDATION}

\section{A. Conclusion}

Based on the research results and discussion there are importance conclusions: (1) the scientific value and economic value are having no significant effect on students' prosocial behavior. The argument is the scientific value tend lead individual to act based on the logical thinking. (2) The power value also has no significant effect on students' prosocial behavior because according it tends to lead an individual to dominate others. (3) The religious value is lack of significant effect of students' prosocial behavior because of religious affection is not always manifest to the religious behavior. The consequence of this point of view is that individual, including students, with well religious affection, is not automatically manifest to prosocial behavior. (4) The solidarity value has a significant effect on students' prosocial behavior because one of the essences of prosocial behavior is solidarity. (5) The art value has a significant effect on students' prosocial behavior because able to lead an individual to develop sensitivity of feeling, the sensitivity of crisis, and empathy. All of them if developed in the personality of individuals are able to race their prosocial behavior.

\section{B. Recommendation}

Based on the conclusion it is recommended that: (1) solidarity value and art value that significantly affect to students' prosocial behavior must develop maximally through various extracurricular activities. (2) The religious value that lack of significant contributes to the students' behavior must develop not only refer to their religious affection but also very important to their religious behaviors. (3) Students' prosocial behavior must develop systematically and well programmed by "Prosocial Guidance Model". Procedures and steps of prosocial guidance model are as illustrated in Table XII. It is can be used not only by counselors but also over the teachers.
TABLE XII. PROSOCIAL GUIDANCE MODEL

\begin{tabular}{|c|c|c|c|}
\hline & $\begin{array}{l}\text { Stages of } \\
\text { guidance }\end{array}$ & The objective of guidance & $\begin{array}{l}\text { Technique of } \\
\text { guidance }\end{array}$ \\
\hline A. & $\begin{array}{l}\text { Setting } \\
\text { potential } \\
\text { problem and } \\
\text { developing } \\
\text { successful } \\
\text { hope }\end{array}$ & $\begin{array}{l}\text { The students are: } \\
\text { 1. Have an awareness that he or } \\
\text { she is not able to help others } \\
\text { is his or her potential problem } \\
\text { 2. To increase successful hope } \\
\text { that he or she is not able to } \\
\text { help others can be solved or } \\
\text { minimally be avoided. }\end{array}$ & $\begin{array}{l}\text { 1. Brainstorming } \\
\text { 2. Question } \\
\text { answer } \\
\text { 3. Sharing information } \\
\text { 4. Lecturing }\end{array}$ \\
\hline B. & $\begin{array}{l}\text { Acquaint-ing } \\
\text { and minimize- } \\
\text { ing biases of } \\
\text { thinking and } \\
\text { feeling }\end{array}$ & $\begin{array}{l}\text { The students are: } \\
\text { 1. Understanding his or her } \\
\text { thinking and feeling about } \\
\text { inability to help others } \\
\text { voluntary } \\
\text { 2. Understanding his or her } \\
\text { biases of thinking and feeling } \\
\text { 3. Minimizing his or her biases } \\
\text { of thinking and feeling that } \\
\text { are not supporting to their } \\
\text { ability on helping others } \\
\text { voluntary. }\end{array}$ & $\begin{array}{l}\text { 1. Self-report } \\
\text { 2. Probing } \\
\text { 3. Comparative } \\
\text { analysis } \\
\text { 4. Discussion }\end{array}$ \\
\hline C. & \begin{tabular}{l|} 
Teaching \\
practice \\
principles of \\
prosocial \\
analysis
\end{tabular} & $\begin{array}{l}\text { The students are: } \\
\text { 1. Distinguish between thinking } \\
\text { and feeling that supporting } \\
\text { and not supporting to their } \\
\text { ability on helping others } \\
\text { voluntary. } \\
\text { 2. Concluding that interpretation } \\
\text { that ability and inability on } \\
\text { helping others voluntary are a } \\
\text { source of the next his or her } \\
\text { behavior. } \\
\text { 3. Having the ability to develop } \\
\text { and maintain his or her } \\
\text { negative thinking and } \\
\text { minimizing them. } \\
\text { 4. Having the ability to choose } \\
\text { positive thinking and feeling. }\end{array}$ & $\begin{array}{l}\text { 1. Giving information } \\
\text { 2. Comparative } \\
\text { analysis } \\
\text { 3. Synthesis evaluative }\end{array}$ \\
\hline & $\begin{array}{l}\text { The solidity of } \\
\text { adaptive and } \\
\text { positive } \\
\text { thinking and } \\
\text { feeling. }\end{array}$ & $\begin{array}{l}\text { The students are: } \\
\text { 1. More firm in maintaining } \\
\text { their adaptive and positive } \\
\text { thinking and feeling } \\
\text { 2. More easily to detached their } \\
\text { negative thinking and feeling. }\end{array}$ & $\begin{array}{l}\text { 1. Reinforcement } \\
\text { 2. Modeling }\end{array}$ \\
\hline
\end{tabular}

\section{REFERENCES}

[1] Andersen, S.M., "Future-Event Schemes and Certainty about the Future: Automatically in Depressives' Future Event Predictions." Journal of Personality and Social Psychology, 1993. 63, p.711-723.

[2] Eisenberg, N.; Fabes, R.A.; Spinrad, T.L. 2007. "Prosocial Development." Handbook of Child Psychology. New York, John Wiley, 2006, pp.646-718.

[3] Sanstock, J.W., A Topical Approach to Live Span Development. New York: McGraw-Hill, 2009, pp.489-491.

[4] Twenge, J.M.; Baumeister, R.F.; Ciarocco, N.J.; dan Bartles, M.J., "Social Exclusion Decrease Prosocial Behavior," Journal of Personality and Social Psychology, 2007, 92, p.56-66.

[5] Eisenberg, N. and Mussen, P.H., The Roots of Prosocial Behavior in Children, Cambridge: Cambridge University Press, 1989, p.3. 
[6] Holliwell, J.F. and Putnam, R.D., "The Social Context of Well Being." Philosophical Transaction of the Royal Society, New York, Biological Sciences, 2010, p.89.

[7] Staubhaar, J.D. et al., Media Now: Understanding Media, Culture, and Technology, Boston, Wadsworth, 2009, pp.427-428.

[8] Decety, J., "The Neuroevolution of Empathy," Annals of the New York Academy of Science, New York, Wiley, 2011, pp.34-35.

[9] Pinel, J., Biopsychology, 8th Edition. New York, Pearson, 2011, p.142.

[10] Asrori, M., Psikologi Pembelajaran. Bandung, Wacana Prima, 2013, p.114.

[11] Asrori, M., Perkembangan Peserta Didik: Penngembangan Kompetensi Pedagogik Guru, Yogyakarta, Media Akademia, 2015, p.146.

[12] Gustavo, C.; Crockett, L.J.; Wolff, N.J.; and Beal, S.J., "The Role of Emotion Reactivity, Self-Regulation, and Puberty in Adolescents' Prosocial Behaviors." Social Development, 2013, 21, p.667-685.

[13] Kartadinata, S., Profil Kemandirian dan Orientasi Timbangan Sosial Mahasiswa serta Kaitannya dengan Perilaku Empatik dan Oriantasi Nilai Rujukan. Bandung: Disertasi Fakultas Pascasarjana IKIP Bandung, 1988, p.83.

[14] Sanusi, A., Beberapa Kecenderungan dalam Studi tentang Perkembangan Moral dan Moralitas. Bandung, P3M UNINUS, 1984, p.9.

[15] Sanusi, A., Jalan Kita di antara Teori-teori tentang Kualitas Kehidupan dan Kepribadian. Bandung, P3M UNINUS, 1985, p.11.

[16] Dovidio, J.F., Helping Behavior and Altruism: An Empirical and Conceptual Overview, New York, Academic Press, 2005, pp.361-427.

[17] Galen, P., "Does Religious Beliefs Promote Prosociality? A Critical Examination, Psychological Bulletin, 2012. 138, p.876-906.

[18] Kerlinger, F.N., Foundations of Behavioral Research. New York,: Harcourt Brace Jovanovich College Publisher, 1986, p.126.

[19] Popham, W.J. \& Sirotnik, K.A., Educational Statistics: Use and Interpretation, Second Edition, New York, Harper \& Row Publisher, 1983, p.19.

[20] Minnium, E.W., Statistical Reasoning in Psychology and Education. New York: John Wiley \& Sons, 1998, p.139.

[21] Kiess, H.O., Statistical Concepts for the Behavioral Sciences. Needham Heights, Massachusetts, Allyn and Bacon, 1989, p.164.

[22] Eagly, E.R., "The His and Hers of Prosocial Behavior: An Examination of the Social Psychology of Gender," American Psychologist, 2014, 24, pp.125-136.

[23] Beutel, J.G. and Johnson, R.L., "Gender and Prosocial Values During Adolescence: A Research Note," Sociological Quarterly, 2014, 45, pp.379-386.

[24] Simon, W., "Relation between Religiousity to Prosocial Behavior," Journal of Personality and Social Psychology, 2014. 43, pp.213-225.

[25] Knickerbocker, R.L., Prosocial Behavior, New York, Center on Philanthropy at Indiana University, 2010, pp.1-3.

[26] Buckley, N.; Siegel, L.S.; and Ness, S.,. Egocentrism, Empathy, and Altruistic Behavior in Young Children. Development Psychology, 2009, 15, pp.329-334. 